\title{
Thermal properties of alkaline and alkaline-earth borate glasses
}

\author{
V.T.Adamiv, Ya.V.Burak, I.S.Girnyk", I.M.Teslyuk \\ Institute of Physical Optics, 23 Dragomanov Str., 79005, Lviv, Ukraine \\ "Scientific-Technical and Educational Center of Low Temperature Studies, \\ I.Franko National University of Lviv, 50 Dragomanov Str., \\ 79005 Lviv, Ukraine
}

\section{Received June 6, 2012}

\begin{abstract}
Results of dilatometric $(80-800 \mathrm{~K})$ and DTA $(293-1200 \mathrm{~K})$ investigations of borate glasses $\mathrm{Li}_{2} \mathrm{~B}_{6} \mathrm{O}_{10}, \mathrm{LiCsB}_{6} \mathrm{O}_{10}, \mathrm{Li}_{2} \mathrm{~B}_{4} \mathrm{O}_{7}, \mathrm{LiKB}_{4} \mathrm{O}_{7}, \mathrm{LiCaBO}_{3}$ and $\mathrm{CaB}_{4} \mathrm{O}_{7}$ in temperature range have been presented. Thermal parameters $T_{g}, T_{D}, T_{p}, T_{m}$ and temperature dependences of thermal expansion coefficient $\alpha(T)$ have been determined and analyzed. It was ascertained that ratios $\mathrm{BO}_{3} / \mathrm{BO}_{4}$, as well as radius and charge of the cations, have an influence on the thermal parameters of the borate glasses.
\end{abstract}

Приведены результаты дилатометрических (80-800 K) и ДТА исследований (293$1200 \mathrm{~K})$ боратных стекол $\mathrm{Li}_{2} \mathrm{~B}_{6} \mathrm{O}_{10}, \mathrm{LiCsB}_{6} \mathrm{O}_{10}, \mathrm{Li}_{2} \mathrm{~B}_{4} \mathrm{O}_{7}, \mathrm{LiKB}_{4} \mathrm{O}_{7}, \mathrm{LiCaBO}_{3}$ и $\mathrm{CaB}_{4} \mathrm{O}_{7}$. Определены и проанализированы тепловые параметры $T_{g}, T_{D}, T_{p}, T_{m}$ и температурные зависимости теплового коэффициента расширения $\alpha(T)$. Установлено, что на тепловые параметры боратных стекол влияют соотношение $\mathrm{BO}_{3} / \mathrm{BO}_{4}$, радиус и заряд катионов.

\section{Introduction}

Borate compounds of alkaline and alkaline-earth elements in form of single crystals, polycrystals and analogous composition glasses present separate wide class of perspective materials for nonlinear optics, laser engineering, thermoluminescent dosimetry and radiation detection. In particular, crystalline $\mathrm{Li}_{2} \mathrm{~B}_{6} \mathrm{O}_{10}, \mathrm{LiCsB}_{6} \mathrm{O}_{10}$, $\mathrm{Li}_{2} \mathrm{~B}_{4} \mathrm{O}_{7}, \mathrm{LiKB}_{4} \mathrm{O}_{7}, \mathrm{LiCaBO}_{3}$ and $\mathrm{CaB}_{4} \mathrm{O}_{7}$ borates, undoped and doped by different elements, already had found their practical applications [1-6]. Nevertheless, growth of the borates single crystals, especially doped ones, is complex and labor-intensive process that has significant influence on cost of final product.

Boric anhydride $\mathrm{B}_{2} \mathrm{O}_{3}$ is very important for current glass technology because both stable oxygen coordinations of boron - triangular $\mathrm{BO}_{3}$ and tetrahedral $\mathrm{BO}_{4}$ have a tendency to polycondensation [7]. And owing to the so called boron anomaly, the structure of borate glasses is very interesting because of variety of the frame modifications and influence of non-bridged oxygen atoms or $\mathrm{M}-\mathrm{O}$ bonds on their optical properties [8]. Technology of the glasses preparation is considerably simpler in comparison with technology of corresponding single crystals growth, because the glasses can be prepared in air atmosphere using comparatively inexpensive ceramic crucibles. Additionally, alloying of the borate glasses is not as critical as in the case of single crystals [9-11], and the glasses can be promising for nanotechnologies, in other words, can be used as matrix for formation of metallic nanoparticles [12], or nanoparticles of the other compounds [13-15].

However for this it is necessary to know thermal parameters of glasses which can be determined from investigations of thermal expansion and differential thermal analysis (DTA). In particular, from temperature de- 
pendences of expansion ratio $\Delta L / L=f(T)$ one can obtain such important thermal parameters of glass as thermal expansion coefficients $\alpha$ (TEC), glass-transition temperature $T_{g}$, which corresponds to viscosity $10^{13.3}$ (or $2 \cdot 10^{13}$ ) Poise and indicates a boundary between solid and viscoplastic conditions of glass (in range $T<T_{g}-$ solid state, and in range $T>T_{g}-$ viscoplastic state), and dilatometric softening temperature $T_{D}$, which is a point of beginning of deformations and corresponds to viscosity $10^{11}$ Poise [16, 17]. From DTA investigations one can obtain a melting temperature value $T_{m}$, crystallization peak $T_{p}$, and other thermal parameters of glass [18].

In the current article, on basis of results of dilatometric in temperature range 80$800 \mathrm{~K}$ and DTA investigations in temperature range 293-1200 $\mathrm{K}$, there were determined and analyzed thermal properties of borate $\quad \mathrm{Li}_{2} \mathrm{~B}_{6} \mathrm{O}_{10}, \quad \mathrm{LiCsB}_{6} \mathrm{O}_{10}, \quad \mathrm{Li}_{2} \mathrm{~B}_{4} \mathrm{O}_{7}$, $\mathrm{LiKB}_{4} \mathrm{O}_{7}, \mathrm{LiCaBO}_{3}$ and $\mathrm{CaB}_{4} \mathrm{O}_{7}$ glasses, obtained by melting in corundum crucibles.

\section{Experimental technique}

Compounds $\mathrm{Li}_{2} \mathrm{~B}_{6} \mathrm{O}_{10}$, $\mathrm{LiCsB}_{6} \mathrm{O}_{10}, \mathrm{Li}_{2} \mathrm{~B}_{4} \mathrm{O}_{7}$, $\mathrm{LiKB}_{4} \mathrm{O}_{7}$, LiCaBO 3 and $\mathrm{CaB}_{4} \mathrm{O}_{7}$ have been obtained by multi-graded temperature synthesis from carbonates $\mathrm{Li}_{2} \mathrm{CO}_{3}, \mathrm{~K}_{2} \mathrm{CO}_{3}, \mathrm{Cs}_{2} \mathrm{CO}_{3}$, $\mathrm{CaCO}_{3}$ and boric acid $\left(\mathrm{H}_{3} \mathrm{BO}_{3}\right)$ of high purity. The glasses have been prepared by standard fusion technique in ceramic $\mathrm{Al}_{2} \mathrm{O}_{3}$ crucibles. Sample from $6 \mathrm{~g}$ of mixture, with chemical formula of corresponding glass, has been mixed and grinded for obtaining highly dispersed homogenous powder. This mixture has been melted and homogenized during $1-2 \mathrm{~h}$ in ceramic $\mathrm{Al}_{2} \mathrm{O}_{3}$ crucible in air atmosphere at temperatures $1270 \mathrm{~K}$ for $\mathrm{Li}_{2} \mathrm{~B}_{6} \mathrm{O}_{10}$, LiCsB $6 \mathrm{O}_{10}, \mathrm{Li}_{2} \mathrm{~B}_{4} \mathrm{O}_{7}$, LiKB $\mathrm{L}_{4} \mathrm{O}_{7}$ and $\mathrm{LiCaBO}_{3}$ glasses, and $1400 \mathrm{~K}$ for $\mathrm{CaB}_{4} \mathrm{O}_{7}$ glass. After homogenization process the crucibles with melt had been taken out of the furnace and after spontaneous cooling to dark red color these had been placed into another furnace, heated to temperature about $680-730 \mathrm{~K}$. After annealing of crucible with glass during $3 \mathrm{~h}$, this furnace was turned off with the following inertial cooling to the room temperature. The obtained glass boule has been taken out of crucible in

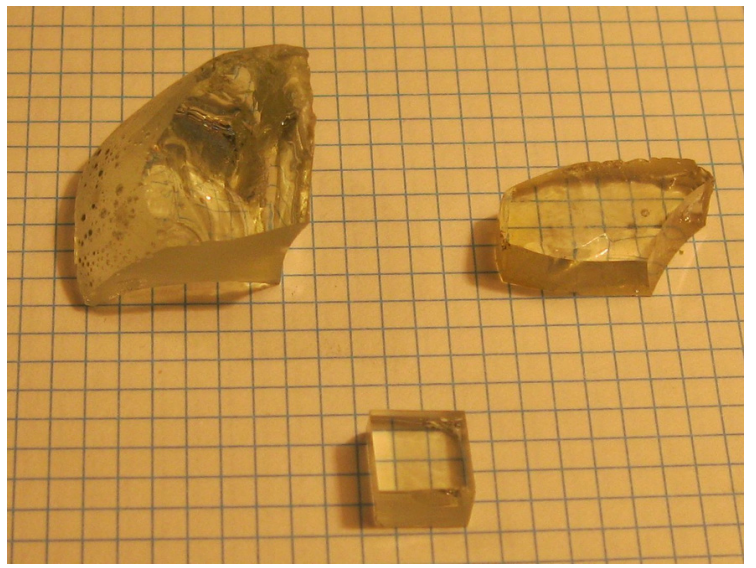

Fig. 1. Photograph of half body and two specimens $\mathrm{LiCaBO}_{3}$ glass.

simple mechanical way. This technique permitted to obtain monolith boules of optical quality even for such difficult in preparation invert glass with two oxides-modifiers as $\mathrm{LiCaBO}_{3}$ (Fig. 1). Noncrystallinity of glasses has been confirmed by X-ray method - diffraction patterns had typical for amorphous materials form without discrete or sharp peaks.

Investigations of thermal expansion have been performed in heating regime on the quartz dilatometer with capacitance recorder of movement with accuracy not less $1 \cdot 10^{-9} \mathrm{~m}$ [19], and temperature rate $1.5 \mathrm{~K} / \mathrm{min}$. Such sensitivity of dilatometer ensures reliable measuring results for relative thermal expansion $\Delta L / L$ on samples with dimensions in direction of measurements, which are given in Table 1. Samples have been cut from annealed glassy boules, and their surfaces have been smoothened and polished. Cross-section of samples was practically equal $6 \times 6 \mathrm{~mm}^{2}$ (diameter of fused quartz stock $\varnothing 6 \mathrm{~mm}$ ). Loading on the sample did not exceed $0.5 \mathrm{~N}$.

Differential-thermal analysis had been performed by derivatograph Q1500D of the Paulik-Paulik-Erdey system under following conditions: initial temperature $293 \mathrm{~K}$, final $1200 \mathrm{~K}$, temperature rate-of-change $10 \mathrm{~K} / \mathrm{min}$. Grinded glass had been loaded into $\mathrm{Pt}$ crucibles, and $\mathrm{Al}_{2} \mathrm{O}_{3}$ powder was used as etalon.

Table 1. Thickness of the glass samples for dilatometric measurements

\begin{tabular}{|c|c|c|c|c|c|c||}
\hline \hline Glass & $\mathrm{Li}_{2} \mathrm{~B}_{6} \mathrm{O}_{10}$ & $\mathrm{LiCsB}_{6} \mathrm{O}_{10}$ & $\mathrm{Li}_{2} \mathrm{~B}_{4} \mathrm{O}_{7}$ & $\mathrm{LiKB}_{4} \mathrm{O}_{7}$ & $\mathrm{LiCaBO}_{3}$ & $\mathrm{CaB}_{4} \mathrm{O}_{7}$ \\
\hline$d, \mathrm{~mm}$ & 9.2 & 12.0 & 9.2 & 9.7 & 7.1 & 6.5 \\
\hline
\end{tabular}




\section{Results and discussions}

Fig. 2 presents the temperature dependences of relative expansion $\Delta L / L=f(T)$ for all investigated glasses: $\mathrm{Li}_{2} \mathrm{~B}_{6} \mathrm{O}_{10}$, $\mathrm{LiCsB}_{6} \mathrm{O}_{10}, \mathrm{Li}_{2} \mathrm{~B}_{4} \mathrm{O}_{7}, \mathrm{LiKB}_{4} \mathrm{O}_{7}, \mathrm{LiCaBO}_{3}$ and $\mathrm{CaB}_{4} \mathrm{O}_{7}$. From these dependences for all glasses there were determined characteristic temperatures $T_{g}$ and $T_{D}$ (marked by arrows on the inset of Fig. 2), which values are given in Table 2.

Temperature dependences of thermal expansion coefficients $\alpha(T)$ in temperature range $T<T_{g}(100-600 \mathrm{~K})$ were obtained by means of computerized numeral differentiation of dependences $\Delta L / L=f(T)$ (step $\Delta T=$ $1 \mathrm{~K}$ ), obtained experimentally. In result, accuracy for a determining was not worth than $\pm 0.2 \cdot 10^{-6} \mathrm{~K}^{-1}$.

Obtained in such way temperature dependences $\alpha(T)$ for all glasses in range $T<$ $T_{g}$ are given in Fig. 3 , and in Table 2 there are presented, respectively, values of $\alpha$ at temperatures 300 and $600 \mathrm{~K}$. As it can be seen from Fig. 3, the temperature dependencies of TEC for all investigated glasses in range $T<T_{g}$ have complex character, which depends on the glass composition and position on temperature scale. One can see that the dependences $\alpha(T)$ of our 6 glasses can be divided into 3 groups: 1) $\mathrm{LiCsB}_{6} \mathrm{O}_{10}$ and $\left.\mathrm{LiKB}_{4} \mathrm{O}_{7} ; 2\right) \quad \mathrm{LiCaBO}_{3}$ and $\mathrm{Li}_{2} \mathrm{~B}_{4} \mathrm{O}_{7} ; 3$ ) $\mathrm{Li}_{2} \mathrm{~B}_{6} \mathrm{O}_{10}$ and $\mathrm{CaB}_{4} \mathrm{O}_{7}$. Glasses of the first group have the highest values of TEC in all temperature range, but these can somewhat differ from their true values for $\mathrm{LiCsB}_{6} \mathrm{O}_{10}$ and $\mathrm{LiKB}_{4} \mathrm{O}_{7}$ glasses, because the diagrams $\Delta L / L=f(T)$ (curves 1 and 2 in Fig. 2) are characteristic for the tempered glasses, as it was shown by authors of the publication [16]. This could mean that despite annealing our $\mathrm{LiCsB}_{6} \mathrm{O}_{10}$ and $\mathrm{LiKB}_{4} \mathrm{O}_{7}$ glasses remained strained. But so far as the character of the dependences $\Delta L / L=f(T)$ for these glasses did not change even after two sessions of

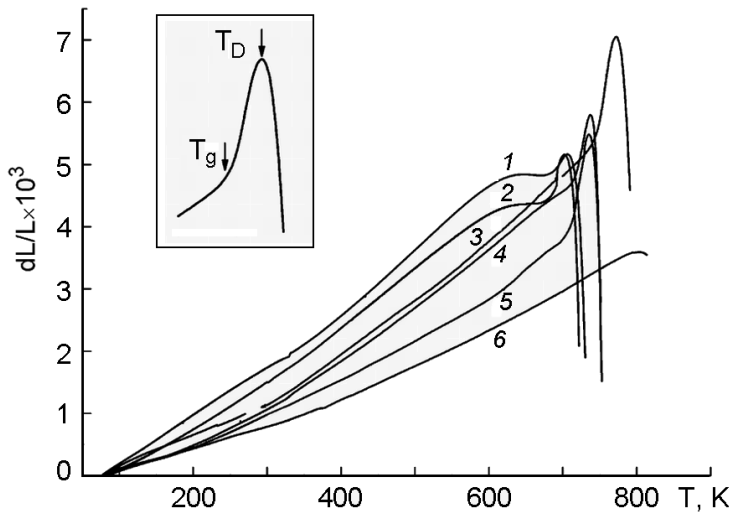

Fig. 2. Temperature dependences of relative expansion of the glasses: $1-\mathrm{LiCsB}_{6} \mathrm{O}_{10} ; 2-$ $\mathrm{LiKB}_{4} \mathrm{O}_{7} ; 3-\mathrm{LiCaBO}_{3} ; 4-\mathrm{Li}_{2} \mathrm{~B}_{4} \mathrm{O}_{7} ; 5-$ $\mathrm{Li}_{2} \mathrm{~B}_{6} \mathrm{O}_{10} ; 6-\mathrm{CaB}_{4} \mathrm{O}_{7}$. The inset shows by arrows the characteristic temperatures $T_{g}$ and $T_{D}$ of the glass.

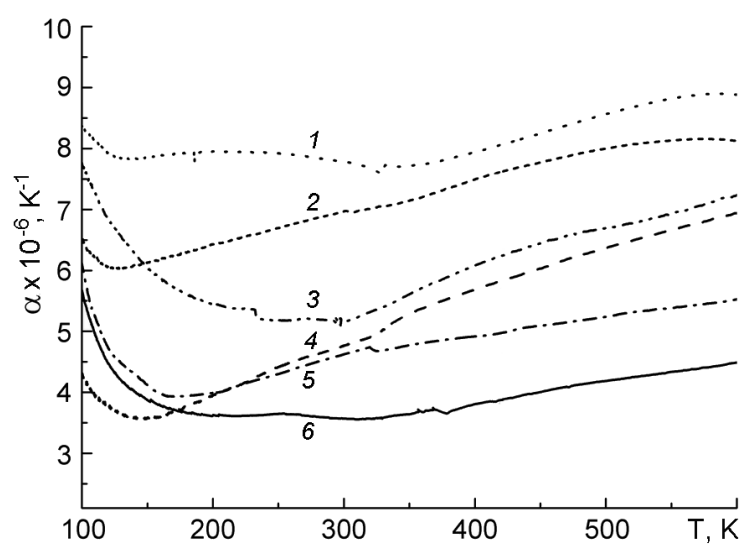

Fig. 3. Temperature dependences $\alpha(T)$ for the glasses: $1-\mathrm{LiCsB}_{6} \mathrm{O}_{10} ; 2-\mathrm{LiKB}_{4} \mathrm{O}_{7} ; 3-$ $\mathrm{LiCaBO}_{3} ; 4-\mathrm{Li}_{2} \mathrm{~B}_{4} \mathrm{O}_{7} ; 5-\mathrm{Li}_{2} \mathrm{~B}_{6} \mathrm{O}_{10} ; 6-$ $\mathrm{CaB}_{4} \mathrm{O}_{7}$.

additional annealing at temperature $700 \mathrm{~K}$, this can denote possible nonthermal origin of the strains in $\mathrm{LiCsB}_{6} \mathrm{O}_{10}$ and $\mathrm{LiKB}_{4} \mathrm{O}_{7}$ glasses, or these strains need some special regimes of annealing. Glasses from

Table 2. TEC and characteristic temperatures for the borate glasses

\begin{tabular}{|c|c|c|c|c|c|c||}
\hline Glass & $\mathrm{LiCsB}_{6} \mathrm{O}_{10}$ & $\mathrm{LiKB}_{4} \mathrm{O}_{7}$ & $\mathrm{LiCaBO}_{3}$ & $\mathrm{Li}_{2} \mathrm{~B}_{4} \mathrm{O}_{7}$ & $\mathrm{Li}_{2} \mathrm{~B}_{6} \mathrm{O}_{10}$ & $\mathrm{CaB}_{4} \mathrm{O}_{7}$ \\
\hline$\alpha_{300 \mathrm{~K}}, 10^{-6} \mathrm{~K}^{-1}$ & 7.8 & 6.9 & 5.2 & 4.8 & 4.7 & 3.6 \\
$\alpha_{600 \mathrm{~K}}, 10^{-6} \mathrm{~K}^{-1}$ & 8.9 & 8.1 & 7.2 & 6.9 & 5.5 & 4.5 \\
$\alpha_{\mathrm{STEC}}, 10^{-6} \mathrm{~K}^{-1}$ & 17.0 & 53.0 & 84.3 & 59.6 & 74.5 & - \\
$T_{g}, \mathrm{~K}$ & 676 & 675 & 744 & 716 & 695 & - \\
$T_{D}, \mathrm{~K}$ & 700 & 700 & 778 & 743 & 737 & $805 ?$ \\
Structure & $2 \mathrm{BO}_{3}+\mathrm{BO}_{4}$ & $5 \mathrm{BO}_{3}+4 \mathrm{BO}_{4}$ & $\mathrm{BO}_{3}[25]$ & $2 \mathrm{BO}_{3}+2 \mathrm{BO}_{4}$ & $2 \mathrm{BO}_{3}+\mathrm{BO}_{4}$ & $4 \mathrm{BO}_{3}+4 \mathrm{BO}_{4}$ \\
& {$[22]$} & {$[24]$} & {$[23]$} & {$[21]$} & {$[26]$} \\
\hline
\end{tabular}


third group $\left(\mathrm{Li}_{2} \mathrm{~B}_{6} \mathrm{O}_{10}\right.$ and $\left.\mathrm{CaB}_{4} \mathrm{O}_{7}\right)$ demonstrate almost analogous with the first group inclinations of the dependences $\alpha(T)$, but with the lowest TEC values in all temperature range. Individual position occupies the second group of $\mathrm{LiCaBO}_{3}$ and $\mathrm{Li}_{2} \mathrm{~B}_{4} \mathrm{O}_{7}$ glasses with their significantly larger angle of inclination for the dependences $\alpha(T)$, whereas their TECs at the room temperature take intermediate values between the first and the third groups (Table 2). Additionally in Table 2 there are given values of the thermal expansion coefficients at temperature $600 \mathrm{~K}$ (from the side of temperatures somewhat lower than $T_{g}$ ) and the so called structural thermal expansion coefficient (STEC) [20], which have been determined in the temperature range exceeding $T_{g}$ by $10-20 \mathrm{~K}$.

The recorded DTA curves for $\mathrm{Li}_{2} \mathrm{~B}_{6} \mathrm{O}_{10}$, $\mathrm{LiCsB}_{6} \mathrm{O}_{10}, \mathrm{Li}_{2} \mathrm{~B}_{4} \mathrm{O}_{7}, \mathrm{LiKB}_{4} \mathrm{O}_{7}$, LiCaBO 3 and $\mathrm{CaB}_{4} \mathrm{O}_{7}$ glasses are shown in Fig. 4. If we use symbols on DTA curves from the publication [27], the first knee from the left on our curves corresponds to temperature $T_{g}$, and maximums after it correspond to the crystallization temperatures of the matrix glass, or its components $T_{p}$ (in Fig. 4 marked by arrows). Sharp minimums, following after this maximum, correspond to the melting temperature $T_{m}$. In particular, for $\mathrm{Li}_{2} \mathrm{~B}_{4} \mathrm{O}_{7}$ (Fig. 4d) and $\mathrm{Li}_{2} \mathrm{~B}_{6} \mathrm{O}_{10}$ (Fig. 4e) glasses one can observe two by two separated melting temperatures. Corresponding characteristic temperatures, determined from the DTA curves, are given in Table 3. Characteristic temperature $T_{D}$ is not fixed on the DTA curves because it is not accompanied by absorption or liberation of heat.

Comparing $T_{g}$ values, presented in Tables 2 and 3 , we can see that for glasses with $\mathrm{Li}$ in composition these temperatures, determined in different experiments (dilatometry and differential thermal analysis), sufficiently well agree. Unfortunately, because of temperature limitation of our installa- tion, it was impossible to reach $T_{m}$ for $\mathrm{CaB}_{4} \mathrm{O}_{7}$ glasses at the DTA curve recording.

It is necessary to note that we obtained significantly smaller $T_{g}$ values for $\mathrm{Li}_{2} \mathrm{~B}_{6} \mathrm{O}_{10}$ and $\mathrm{Li}_{2} \mathrm{~B}_{4} \mathrm{O}_{7}$ glasses in comparison with the expected $T_{g}$, determined by data base from SciGlass Professional 7.2. This can be explained by peculiarities of our method for glasses preparation that leads to particular dissolution of the crucible material $\mathrm{Al}_{2} \mathrm{O}_{3}$ in borate melt [28]. In this work it was ascertained with the aim of X-ray microanalyzer of the scanning microscope PEMMAS-10202 that content of $\mathrm{Al}_{2} \mathrm{O}_{3}$ in the lithium-borate glasses can reach $8 \mathrm{~mol} \%$, whereas in $\mathrm{CaB}_{4} \mathrm{O}_{7}$ glass - only $2.5 \mathrm{~mol}$ \% . And from the publication [20] it is known that small admixtures of $\mathrm{Al}_{2} \mathrm{O}_{3}$ decrease $T_{g}$ for borate glasses. Also it is necessary to note that because of this fact our values $T_{g}$ for $\mathrm{Li}_{2} \mathrm{~B}_{4} \mathrm{O}_{7}$ and $\mathrm{LiKB}_{4} \mathrm{O}_{7}$ glasses (Table 3) somewhat differ from the values presented by authors of the publication [27] $\left(T_{g}=760 \mathrm{~K}\right.$ and $T_{p}=808 \mathrm{~K}$ for $\mathrm{Li}_{2} \mathrm{~B}_{4} \mathrm{O}_{7} ; T_{g}=686 \mathrm{~K}$ and $T_{p}=840 \mathrm{~K}$ for $\mathrm{LiKB}_{4} \mathrm{O}_{7}$, obtained also from DTA). Deviation in the values $T_{g}$ are the following: $\Delta T_{g}=47$ and $13 \mathrm{~K}$ for $\mathrm{Li}_{2} \mathrm{~B}_{4} \mathrm{O}_{7}$ and $\mathrm{LiKB}_{4} \mathrm{O}_{7}$, respectively.

Indeed, the most intensive peak $T_{p}$ with heat liberation on the DTA curves must relate to the crystallization $T_{p}$ of the main compound, which is defined by chemical formula of the borate glass. Therefore, in $\mathrm{Li}_{2} \mathrm{~B}_{4} \mathrm{O}_{7}$ glass at $T_{p}=823 \mathrm{~K}$, compound $\mathrm{Li}_{2} \mathrm{~B}_{4} \mathrm{O}_{7}$ begins to crystallize, and it is confirmed by high intensity of peak on the DTA curve and by the carefully studied state diagram for $\mathrm{Li}_{2} \mathrm{O}-\mathrm{B}_{2} \mathrm{O}_{3}$ system in the work [29]. And in $\mathrm{Li}_{2} \mathrm{~B}_{6} \mathrm{O}_{10}$ glass the most intensive peak at $T_{p}=862 \mathrm{~K}$ indicates beginning of crystallization for $\mathrm{Li}_{2} \mathrm{~B}_{6} \mathrm{O}_{10}$ compound. Additional $T_{p}$ peaks of small intensity in $\mathrm{LiCsB}_{6} \mathrm{O}_{10}, \mathrm{LiKB}_{4} \mathrm{O}_{7}$, $\mathrm{LiCaBO}$ glasses can indicate the selection of other crystallized phases with different chemical formulas. But it is very problematical to examine by X-ray analysis which phases are crystal-

Table 3. Characteristic temperatures $T_{g}, T_{p}$ and $T_{m}$ determined from DTA curves for the borate glasses

\begin{tabular}{|c|c|c|c|c|c|c||}
\hline \hline Glass & $\mathrm{LiCsB}_{6} \mathrm{O}_{10}$ & $\mathrm{LiKB}_{4} \mathrm{O}_{7}$ & $\mathrm{LiCaBO}_{3}$ & $\mathrm{Li}_{2} \mathrm{~B}_{4} \mathrm{O}_{7}$ & $\mathrm{Li}_{2} \mathrm{~B}_{6} \mathrm{O}_{10}$ & $\mathrm{CaB}_{4} \mathrm{O}_{7}$ \\
\hline$T_{g}, \mathrm{~K}$ & 673 & 673 & 743 & 713 & 699 & 883 \\
$T_{p}, \mathrm{~K}$ & 773 & 753 & 843 & $823^{*}$ & $862^{*}$ & 965 \\
& 828 & $813^{*}$ & $985^{*}$ & 1088 & 1032 & $>1000^{*}$ \\
& 913 & 923 & & & & - \\
$T_{m}, \mathrm{~K}$ & 1118 & 993 & 1050 & 1073 & 1066 & - \\
\hline
\end{tabular}



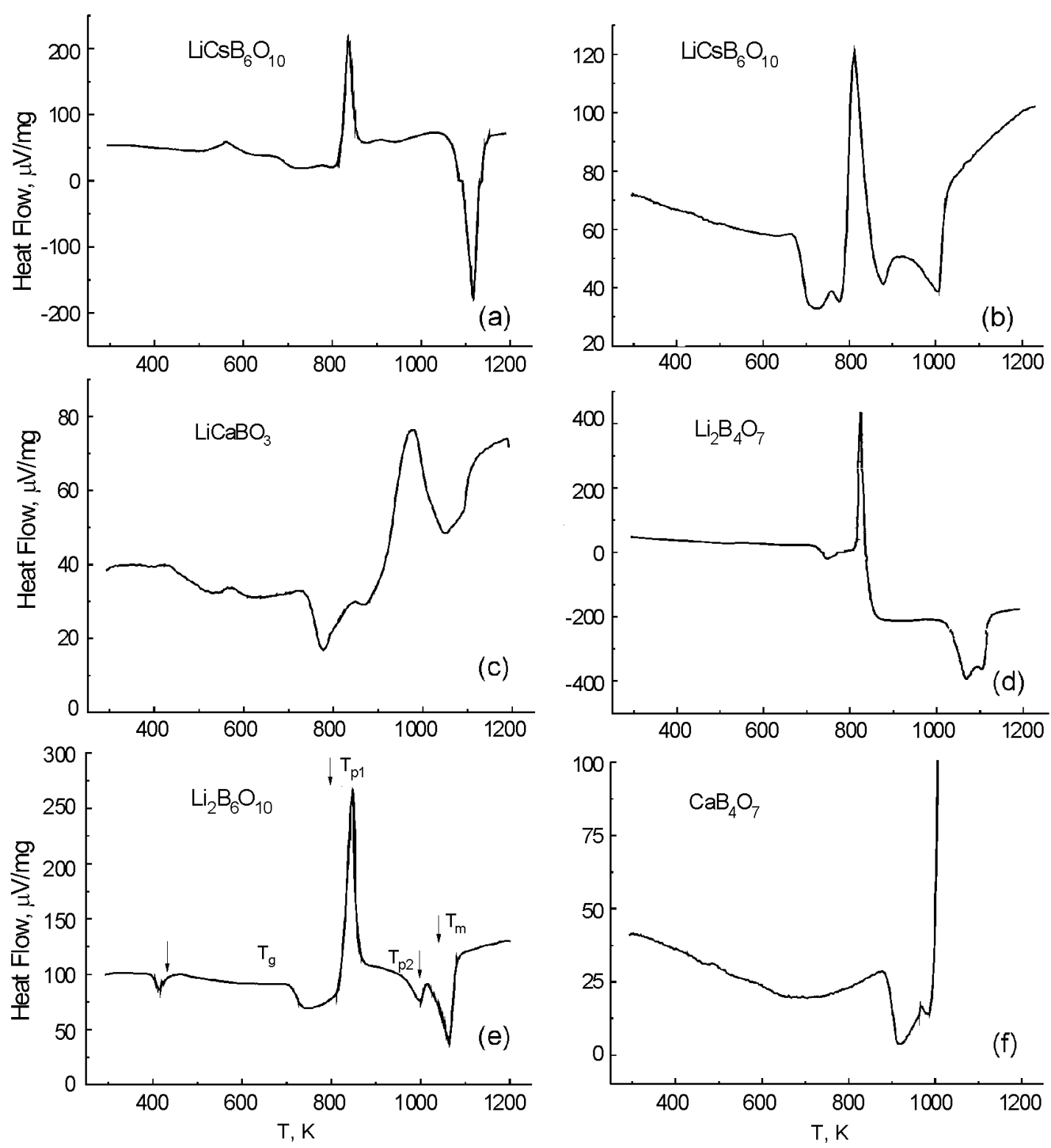

Fig. 4. DTA curves for the glasses: (a) $-\mathrm{LiCsB}_{6} \mathrm{O}_{10}$; (b) $-\mathrm{LiKB}_{4} \mathrm{O}_{7}$; (c) $-\mathrm{LiCaBO}_{3}$; (d) $-\mathrm{Li}_{2} \mathrm{~B}_{4} \mathrm{O}_{7}$; (e) $-\mathrm{Li}_{2} \mathrm{~B}_{6} \mathrm{O}_{10}$; (f) $-\mathrm{CaB}_{4} \mathrm{O}_{7}$.

lized at these temperatures, because each one must be released for more than $2 \%$ in the glass.

Selection of the compositions of our borate glasses permits to analyze the influences of structural factors (boron-oxygen anion frames) together with size and charge of the cations $\left(\mathrm{Li}^{+}-0.68 \AA, \mathrm{K}^{+}-1.33 \AA\right.$, $\mathrm{Cs}^{+}-1.67 \AA$ and $\mathrm{Ca}^{2+}-0.94 \AA$ ) on their thermal parameters. Boron-oxygen complexes characteristic for our borate compounds are formed from the elementary complexes (boron in three-coordinate $\mathrm{BO}_{3}$, and boron in tetrahedral oxygen environ- ment $\mathrm{BO}_{4}$ ) and presented in Table 2. As known, the structural frame of glass from boric anhydride $\mathrm{B}_{2} \mathrm{O}_{3}$ is formed only from $\mathrm{BO}_{3}$ elementary complexes, whereas addition of alkaline or alkaline-earth elements leads to change of the boron oxygen coordination from 3 to 4 , i.e., formation of $\mathrm{BO}_{4}$ elementary complexes by scheme [30]:

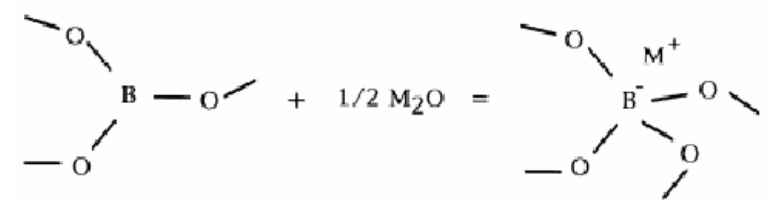


Thereby, with increasing of concentration of the cations the number of $\mathrm{BO}_{4}$ complexes increases sufficiently quickly, and undirected ionic bonds between the cations and boron-oxygen anions begin to have noticeable influence on thermal expansion of the glass. In our case this is well observed under comparison of the results for $\mathrm{Li}_{2} \mathrm{~B}_{6} \mathrm{O}_{10}$ and $\mathrm{Li}_{2} \mathrm{~B}_{4} \mathrm{O}_{7}$ glasses (or in another transcription $\mathrm{Li}_{2} \mathrm{O} \cdot 3 \mathrm{~B}_{2} \mathrm{O}_{3}$ and $\mathrm{Li}_{2} \mathrm{O} \cdot 2 \mathrm{~B}_{2} \mathrm{O}_{3}$, respectively). Because in $\mathrm{Li}_{2} \mathrm{~B}_{6} \mathrm{O}_{10}$ compound there are $25 \%$ molar $\mathrm{Li}_{2} \mathrm{O}$ at ratio $\mathrm{BO}_{3} / \mathrm{BO}_{4}$ $=2: 1$, whereas in $\mathrm{Li}_{2} \mathrm{~B}_{4} \mathrm{O}_{7}$ there are $33.3 \%$ molar $\mathrm{Li}_{2} \mathrm{O}$ at ratio $\mathrm{BO}_{3} / \mathrm{BO}_{4}=2: 2$ (see Table 2). Correspondingly, the glass-transition temperature $T_{g}$ are smaller for $\mathrm{Li}_{2} \mathrm{~B}_{6} \mathrm{O}_{10}$ glass than for $\mathrm{Li}_{2} \mathrm{~B}_{4} \mathrm{O}_{7}$ glass. Analogous picture would be observed also for TEC [31] in these glasses, because increasing of 4-coordinate boron in the glass with growth of alkali cations concentration makes the boron-oxygen complex more rigid. But in our case this condition is fulfilled only at temperatures lower than $200 \mathrm{~K}$, and at higher temperatures there is observed the adverse picture (see Fig. 3, curves 4 and 5). Such distinction from expected TEC behavior can be connected with inclusion of $\mathrm{Al}_{2} \mathrm{O}_{3}$ in the glass at its preparation in the appropriate ceramic crucibles.

Analysis of the obtained results for $\mathrm{Li}_{2} \mathrm{~B}_{6} \mathrm{O}_{10}$, LiCsB $6 \mathrm{O}_{10}$ and $\mathrm{Li}_{2} \mathrm{~B}_{4} \mathrm{O}_{7}$, LiKB $\mathrm{O}_{7}$ glasses very well illustrates an influence of alkali ion sizes on the thermal parameters of borate glasses. Therefore, at substitution of half of $\mathrm{Li}^{+}(0.68 \AA)$ ions by $\mathrm{Cs}^{+}(1.67 \AA)$ ions with larger radius for the first pair of $\mathrm{Li}_{2} \mathrm{~B}_{6} \mathrm{O}_{10}$ and $\mathrm{LiCsB}_{6} \mathrm{O}_{10}$ glasses, or half of $\mathrm{Li}^{+}$ions by $\mathrm{K}^{+}(1.33 \AA)$ for the second pair of $\mathrm{Li}_{2} \mathrm{~B}_{4} \mathrm{O}_{7}$ and $\mathrm{LiKB}_{4} \mathrm{O}_{7}$ glasses, the glasstransition temperatrure $T_{g}$ and STEC decrease, whereas the TEC increases. So, taking into account presence of the cations with larger sizes and the similar complicated boron-oxygen complexes - anions in $\mathrm{LiCsB}_{6} \mathrm{O}_{10}$ and $\mathrm{LiKB}_{4} \mathrm{O}_{7}$ glasses, we can also explain their typing to one common group by the dependences $\alpha(T)$.

Appearance of two-charge alkali-earth $\mathrm{Ca}^{2+}$ ions with similar to $\mathrm{Li}^{+}$sizes $\left(r_{\mathrm{Ca}^{2+}}=\right.$ $0.94 \AA$ ) in the borate glass also has essential influence on the structure and thermal parameters. In particular, for the structure of $\mathrm{LiCaBO}_{3}$ compound (molar part of $\mathrm{B}_{2} \mathrm{O}_{3}$ equals $25 \%$ ) the presence of only $\mathrm{BO}_{3}$ complexes [25], is characteristic feature, while for $\mathrm{CaB}_{4} \mathrm{O}_{7}$ compound the presence of $4 \mathrm{BO}_{3}$ $+4 \mathrm{BO}_{4}$ complexes [26], is characteristic; these complexes form their boron-oxygen frames in the corresponding glasses. And if for $\mathrm{LiCaBO}_{3}$ glass the dependence $\alpha(T)$ at $T<T_{g}$ is almost analogous to $\mathrm{Li}_{2} \mathrm{~B}_{4} \mathrm{O}_{7}$ glass, then the glass-transition temperature $T_{g}$ and STEC are significantly higher. In $\mathrm{CaB}_{4} \mathrm{O}_{7}$ glass, in which the molar part of $\mathrm{B}_{2} \mathrm{O}_{3}$ equals now $33.3 \%$, the situation is completely different: TEC have the lowest values in all set of the investigated borate glasses, and it is impossible to determine such parameters as $T_{g}$ and STEC from the dependency $\Delta L / L=f(T)$ (curve 6 on Fig. 2). Only on the basis of DTA data it became possible to determine the glass-transition temperature $T_{g}=883 \mathrm{~K}$ for $\mathrm{CaB}_{4} \mathrm{O}_{7}$ glass. Therefore, our results, obtained for $\mathrm{LiCaBO}_{3}$ and $\mathrm{CaB}_{4} \mathrm{O}_{7}$ glasses, can indicate the presence of so called boric anomaly at introduction of the impurity of alkali-earth elements $\mathrm{M}^{2+}$ into boric anhydride $\mathrm{B}_{2} \mathrm{O}_{3}$, analogously with experimentally observed the same anomaly for alkali elements [32]. Something similar was observed also for $\mathrm{Pb}^{2+}$ ions in $\mathrm{PbO}-\mathrm{B}_{2} \mathrm{O}_{3}$ glasses, what can be seen in Fig. 32 in review article of A.C.Wright [33].

\section{Conclusions}

For the borate glasses $\mathrm{Li}_{2} \mathrm{~B}_{6} \mathrm{O}_{10}$, $\mathrm{LiCsB}_{6} \mathrm{O}_{10}, \mathrm{Li}_{2} \mathrm{~B}_{4} \mathrm{O}_{7}, \mathrm{LiKB}_{4} \mathrm{O}_{7}, \mathrm{LiCaBO}_{3}$ and $\mathrm{CaB}_{4} \mathrm{O}_{7}$, obtained by fusion in corundum crucibles, there were performed dilatometric and DTA investigations in wide temperature range. For all glasses the thermal parameters $T_{g}, T_{D}, T_{p}$ and $T_{m}$ as well as TEC and STEC were determined and analyzed. From the DTA investigations it was ascertained that in all investigated by us borate glasses the weak peaks with heat liberation exist, which can correspond to $T_{p}$ of the borate compounds differing from the basic one, defined by the chemical formula. It was revealed that ratios $\mathrm{BO}_{3} / \mathrm{BO}_{4}$, as well as radius and charge of the cations, have an influence on the thermal parameters of the borate glasses. By dependences $\alpha(T)$ in the range of $T<T_{g}$ all glasses can be divided into following 3 groups: 1) $\mathrm{LiCsB}_{6} \mathrm{O}_{10}$ and $\mathrm{LiKB}_{4} \mathrm{O}_{7}$, 2) $\mathrm{LiCaBO}_{3}$ and $\mathrm{Li}_{2} \mathrm{~B}_{4} \mathrm{O}_{7}, 3$ ) $\mathrm{Li}_{2} \mathrm{~B}_{6} \mathrm{O}_{10}$ and $\mathrm{CaB}_{4} \mathrm{O}_{7}$. By similarity of the structural factors and presence of the cations with large radius one can explain belonging to one group only for $\mathrm{LiCsB}_{6} \mathrm{O}_{10}$ and $\mathrm{LiKB}_{4} \mathrm{O}_{7}$ glasses, whereas the principles of grouping for other two pairs of glasses do not have single-valued explanation. 
Acknowledgments. This work was supported by Science and Technology Center in Ukraine, Project 4947.

\section{References}

1. Y.Ebata, H.Suzuki, S.Matsumura et al., Jpn. J.Appl.Phys., 22, 160 (1983).

2. S.Fan, G.Chen, W.Wang et al., J.Cryst. Growth, 99, 811 (1997).

3. I.Martynyuk-Lototska, O.Mys, O.Krupych et al., Integrated Ferroelectrics, 63, 99 (2004).

4. P.Li, Z.Wang, Z.Yang et al., J.Luminescence, 130, 222 (2010).

5. Y.Fukuda, N.Takeuchi, J.Mat.Sci.Lett., 5, 379 (1986).

6. Yu.Oseledchyk, A.Prosvirin, A.Pisarevskiy, Opt. Mat., 4, 669 (1995).

7. W.Soppe, F.Aldenkamp, H.W.Hartog, J.NonCryst.Sol., 91, 351 (1987).

8. G.D.Cryssicos, E.I.Kamitsos, M.A.Karakassides, Phys. Chem. Glasses, 31, 109 (1990).

9. B.Padlyak, W.Ryba-Romanowski, R.Lisiecki et al., J.Non-Cryst.Sol., 356, 2033 (2010).

10. B.Padlyak, W.Ryba-Romanowski, R.Lisiecki et al., A. Opt. Appl., 40, 427 (2010).

11. B.Padlyak, W.Wojtowicz, V.Adamiv et al., Acta Phys. Polonica, 117, 122 (2010).

12. M.E.Miller, J.E.Shelby, Phys. Chem. Glasses, B 51, 100 (2010).

13. E.K.Abdel-Khalek, A.A.Bahgat, Physica B: Condens. Matter, 405, 1986 (2010).

14. W.E.F.Ayta, V.A.Silva, N.O.Dantas, J.Luminescence, 130, 1032 (2010).

15. K.B.Aleynikova, E.N.Zinchenko, R.S.Bubnova et al., Glass Phys. Chem., 35, 284 (2009).
16. O.Mazurin, A.Totesh, M.Streltsyna et al., Teplovoye Razshyreniye Stekla, Nauka, Leningrad (1969) [In Russian].

17. A.D.Sontakke, K.Biswas, A.Tarafder et al., Opt.Mat.Express, 1, 344 (2011).

18. Yu.Voronko, S.Galaktionov, L.Dmitruk et al., Glass Phys. Chem., 32, 1 (2006).

19. I.Girnyk, V.Adamiv, Ya.Burak et al., Ukr.J. Phis., 44, 1102 (1999).

20. V.P.Klyuev, B.Z.Pevzner, I.G.Polyakova, Phys. Chem. Glasses: Eur.J.Glass Sci. Technol., B 47, 524 (2006).

21. H.Von Koenig, R.Hoppe, Z.Anorg.Allg. Chem., 489, 71 (1978)

22. T.Sasaki, Y.Mory, I.Kuroda et al., Acta. Cryst., C51, 2222 (1995).

23. S.Radajev, L.Muradyan, L.Malakhova et al., Sov. Phys. Crystallogr., 34, 842 (1989).

24. Y.Ono, M.Nakaya, T.Kajitani et al., Acta Cryst., C56, 1413 (2000).

25. L.Wu, X.L.Chen, H.Li et al., J.Sol.State Chem., 177, 1111 (2004).

26. N.V.Zayakina, A.A.Browkin, Sov.Phys.Crystallogr., 22, 156 (1977).

27. G.Paramesh, R.Vaish, K.B.R.Varma, J.Noncrystal. Solids, 357, 1479 (2011).

28. V.T.Adamiv, Ya.V.Burak, R.V.Gamernyk et al., Functional Materials, 18, 298 (2011).

29. B.S.R.Sastry, F.A.Hummel, J.Am.Ceram. Soc., 42, 216 (1959).

30. M.Janssen, H.Eckert, Solid State Ionics, 136-137, 1007 (2000).

31. D.R.Uhlman, R.R.Shaw, J.Non-Cryst.Solids, 1, 347 (1969).

32. J.E.Shelby, J.Am.Ceram.Soc., 66, 225 (1983).

33. A.C.Wright, Phys. Chem. Glasses: Eur. J.Glass Sci. Technol. B, 51, 1 (2010).

\title{
Теплові властивості лужних і лужноземельних боратних стекол
}

\author{
В.Т.Адамів, Я.В.Бурак, І.С.Гірник, І.М.Теслюк
}

Наведено результати дилатометричних $(80-800 \mathrm{~K})$ та ДТА досліджень (293-1200 K) боратних стекол $\mathrm{Li}_{2} \mathrm{~B}_{6} \mathrm{O}_{10}, \mathrm{LiCsB}_{6} \mathrm{O}_{10}, \mathrm{Li}_{2} \mathrm{~B}_{4} \mathrm{O}_{7}, \mathrm{LiKB}_{4} \mathrm{O}_{7}, \mathrm{LiCaBO}_{3}$ i $\mathrm{CaB}_{4} \mathrm{O}_{7}$. Визначено $\mathrm{i}$ проаналізовано теплові параметри $T_{g}, T_{D}, T_{p}, T_{m}$ і температурні залежності теплового коефіцієнта розширення $\alpha(T)$. Встановлено, що на теплові параметри боратних стекол впливають співвідношення $\mathrm{BO}_{3} / \mathrm{BO}_{4}$, радіус і заряд катіонів. 